\title{
DENÚNCIAS POLÍTICAS E LEGALISMOS NA PRIMEIRA REPÚBLICA BRASILEIRA PELA REVISTA DE CRÍTICA JUDICIÁRIA (1924-1940).
}

\author{
Stéphani Fleck da Rosa ${ }^{1}$
}

\begin{abstract}
Resumo
Este artigo se pretende analisar a discussão travada ao longo da Revista de Crítica Judiciária sobre os três poderes brasileiros na primeira metade do século XX. Mostra retratos de fatos revistos pela lente jurídica, nos quais seus editores travam argumentos sobre os mandos da classe política, de governantes e dos operadores do direito. Representa por seus escritos uma importante fonte histórica do direito e também da sociedade brasileira.

Palavras-chave: Primeira República; História do Direito; Três Poderes; Governo; Abusos de Poder

\section{POLITICAL COMPLAINTS AND LEGALISMS OF BRAZIL FIRST REPUBLIC IN CRITICA JUDICIARIA REVIEW (1924-1940).}

\begin{abstract}
This article aims to study the discussion held throughout the Critica Judiciaria Review on the three Brazilian powers in the first half of the 20th century. It shows facts reviewed by the legal lens, in which their editors make arguments about the mandates of the political class, of governors and of the operators of law. It represents by its writings an important legal historical source and also to Brazilian society.
\end{abstract}

Keywords: First Republic; Legal History; Three Powers; Government; Power Abuses

\section{INTRODUÇÃO}

Os enlaces entre a política e o direito apresentam-se em inúmeros momentos, nas páginas da Revista de Crítica Judiciária. Casos curiosos e de pouca repercussão na historiografia brasileira, a saber, uma rebelião insurgida em Manaus ${ }^{2}$, na década de 20, até notórios fatos políticos e históricos, movimento revolucionário de 1930, possuem palco nos debates travados dentro desta publicação jurídica. A preocupação do tratamento jurisprudencial adequado às leis e aos aspectos morais e sociais pela formação de um debate político-jurídico nacional posiciona a Revista como um ator fecundante da crítica ao cenário

\footnotetext{
${ }^{1}$ Bolsista produtividade CNPQ e Doutoranda em Direito pelo PPGD da Faculdade de Direito da UFRGS

2Veja: (...) é apelante o juiz federal da secção do Amazonas, são recorrentes o capitão J. C. D., primeiro tenente $J$. de M. C. B., primeiro tenente A. A. R. J., primeiro tenente R. V. F., e grande numero de officiais do vigésimo sexto batalhão de caçadores e civis envolvidos no movimento sedicioso que rebentou no Estado do Amazonas (...) FERRREIRA, Vieira. Crime político. Competencia do Tribunal do Jury para julga-lo. Revista de Crítica Judiciária, Rio de Janeiro, v. 4, n.1, jul.1926, p. 44.
} 
nacional. Assim, pela leitura do conjunto de suas edições, fio possível separá-las em textos em temas que criticam de alguma forma os abusos dos três poderes, em um período conturbado que foi a primeira metade do século XX no país.

Um dos debates expostos pela crítica da Revista, a partir da proposta de mudança da capital do presidente da República brasileira, Washington Luiz, pelo disposto no artigo terceiro da Constituição Federal de 1891, o qual destina área no planalto central para a capital do país, discute-se a validade dessa mudança (FERREIRA, 1926). Uma localização mais central, não litorânea, diversa da capital à época, Rio de Janeiro, porém questiona-se como se daria a comunicação do novo centro de poder federal com o resto do país a faltar estradas que os conectem? E a vida urbana necessária a uma capital, mesmo que os argumentos se direcionem para a inconveniência das cidades populosas, ausente no interior do planalto central? Encerra-se pela discussão da capital política poder ser diversa da capital biodinâmica, a saber, um núcleo populacional do país, no entanto, há a concorrência dos dados demográficos e mesológicos com os étnicos e históricos.

Discute-se a harmonia dos poderes através do impasse entre o poder executivo e o poder judiciário sobre de qual autoridade deveria dar a ordem de expulsão a estrangeiro, retratando o clima de instabilidade nacional e internacional no ano de $1929^{3}$. Quais os ditames para identificar um "elevado interesse nacional" no caso dessa expulsão, a fim de não caracterizar uma perseguição política institucional? O abuso de poder entra em pauta, a Revista reforça a atuação do poder judiciário como defensor da legalidade e deúncia processos arranjados por elementos subalternos e corruptos da polícia contra estrangeiros, os quais pouca segurança no território sede tinha naqueles tempos.

Quanto à suspensão de direitos políticos definitiva de qualquer cidadão desde condenado criminalmente, à luz de 1930, critica-se a dupla consequência de que essa suspensão representaria, mesmo que herdado de legislações anteriores. $O$ direito constitucional é analisado conjuntamente ao direito penal em relação a sentença criminal que ela só possui efeitos suspensivos de direitos políticos pelo tempo do cumprimento da pena, restringindo, pois, a liberdade do sujeito. Desse modo, limita-se a suspensão dos direitos políticos pela autoridade pública.

3Veja: "NÃO SENDO POSSIVEL, PORQUE CONTRARIA A HARMONIA DOS PODERES A EXPULSÃO DO ESTRANGEIRO INDESEJÁVEL SUJEITO DE PROCESSO CRIMINAL, NÃO É LÍCITA A SUA PRISÃO ADMINISTRATIVA PARA AQUELE FIM." CARVALHO, Abílio de. Supremo Tribunal Federal. Revista de Crítica Judiciária, Rio de Janeiro, v. 9, n. 1, jan.1929, p. 6- 12. 
A Revista traz análises sobre os três poderes neste tempo conturbado que foi a primeira metade do século XX, fazendo seu papel de crítica no campo social, no qual seus editores compõem um grupo restrito da elite intelectual brasileira, também como operadores do direito (ROSA, 2020).

\section{OS MANDOS E DESMANDOS DO EXECUTIVO}

A organização federativa brasileira na Primeira República foi protagonista de muitos impasses no âmbito dos três poderes, principalmente no Poder Executivo e suas controvérsias administrativas, tal como a autonomia municipal. A Revista de Crítica Judiciária expõe criticamente que o modo autônomo é dado em graus do estado e do município no ordenamento constitucional da aurora republicana, referencia-se a teoria do contrato social que abrange a construção política piramidais, cuja base é composta por pequenas associações de indivíduos e cujo vértice há uma união superior de combinações de estratos sociais intermediários, consoante Jean Jacques Rousseau (FERREIRA, 1928). Critica-se o sistema de federativo adotado pelo Brasil pela busca por se assemelhar ao sistema norte-americano, como uma verdadeira alienação da realidade do país, composto por vultosas desigualdades regionais ${ }^{4}$.

Reconhece-se o exagero na descentralização do poder central realizada no governo republicano, cabendo aos estados e municípios optarem por ser integrante do povo brasileiro ou não dependendo dos seus interesses, independente da utilidade pública federal. A discussão sobre o respaldo constitucional acerca da nomeação do agente executivo do município é dada por qual dos entes, União ou estado, possuiriam tal autoridade. A publicação critica igualmente a imprecisão do modo que a autonomia dos municípios é dada de acordo com um interesse peculiar.

Assim, por exemplo, na cidade em que se acha a capital do estado a administração local não é de interesse peculiar ao município, pois este seria sede do governo do estado, sendo seus serviços mais de interesse deste que do município, ou seja, o interesse da capital prevaleceria sobre o do município, tornando compatível esse manuseio de mando

4Veja: "Compreende-se uma câmara municipal em Campos ou em Juiz de Fora, mas em certas povoações em que o paço da câmara se ergue solitário, por não haver quase outra casa, o município de Xibuá, por exemplo, no Amazonas, a organização administrativa torna-se irrisória. (FERREIRA, 1928). 
com o modo autônomo federado regido no país daquele tempo em contraposição a um interesse peculiar municipal. Esse posicionamento é marcado na Revista, inclusive pela elaboração de um de seus diretores de projeto sobre as dívidas dos municípios, o qual demonstra que autonomia municipal cederia diante de um interesse mais alto como o da justiça ${ }^{5}$.

Mais uma controvérsia apresentada pela publicação é dos abusos realizados pelo Poder Executivo e seu poder de polícia nos casos de vadiagem e de presos políticos no Brasil republicano. A repressão à vadiagem, pela caracterização deste crime, compõe um longo dissídio entre a magistratura e a polícia republicana registrado na Revista, do seu início que havia alguma harmonia entre estes entes estatais com o aval dos juízes aos atos mesmo que simplistas e arbitrários de certas autoridades policiais. Contudo, a força policial calcada em outros preconceitos serviu-se do mal da vadiagem, ao exercer perseguições a indivíduos apanhados nas ruas e nas moradias, através de processos irregulares, por depoimentos prédeterminados, atentando contra a legalidade ${ }^{6}$.

Em igual medida era o abuso do Executivo conferido na situação dos presos políticos do período da Primeira Republica, acentuado nos regimes de governo posteriores, notoriamente no caso dos estrangeiros imigrantes. A Revista de Crítica Judiciária atesta a ilegalidade dos indeferimentos de habeas-corpus dados nesses casos, bem como dos descumprimentos de cárcere especial a esses presos, diverso dos presos de crimes comuns ${ }^{7}$. Adentra-se a crítica nos ditames do direito de corrigir os arbítrios e os abusos do Executivo no

5Veja: "Condenado o município a pagar a quantia liquida, ou liquidável na execução, executar-se-a o julgado pela forma seguinte: 1) O credor será pago, mediante precatória dirigida ao intendente, pelas verbas destináveis aos pagamentos das dividas exigíveis. 2) Se essas verbas não forem bastantes, o Conselho a requerimento do exequente, do que se lhe dará recibo, incluirá a divida no orçamento do ano seguinte. 3) Se o não fizer, poderão ser penhorados os bens dominicais do município e, não havendo ou não sendo bastantes, o juiz, a requerimento do exequente, incluirá a divida no orçamento do municipal e indicará o titulo da receita destinado ao pagamento. 4) Se nem assim for satisfeito o exequente, o governador, nomeará um intendente, que exercerá o cargo até se realizar o pagamento, ficando suspenso o efetivo." (FERREIRA, 1928).

6 Veja: "Chegou-se ao cumulo de mandar oficialmente imprimir, para uso das delegacias, modelos desses depoimentos". MORAES, Evaristo de. Atentados da autoridade policial. Revista de Crítica Judiciária, Rio de Janeiro, v. 8, n. 1, jul. 1928, p. 44.

7 Veja: “- Ora o paciente alegou que está incomunicável, e o Governo prestou informação, em sentido contrário. Logo, não podia o Tribunal recusar ao paciente, o único ensejo, que se lhe oferecia provar, pelo seu comparecimento em juízo, que a informação do Governo não é verdadeira, tanto mais quanto já tem ele prestado informações falsas". Este final parece grave, o Ministro Hermenegildo, porém, prova-o: "Assim, a alegação de presos políticos de estarem recolhidos a lugares destinados a réus de crimes comuns, o Governo informou que eles não estavam, em cubículos, da Casa de Detenção, mas em lugares separados desses cubículos. Entretanto, os presos conseguiram provar, por meio de fotografias, que se encontram no habeascorpus n. 12.128, o recolhimento, em cubículos da Casa de Detenção de presos políticos, entre os quais o General Ximeno Villeroy. 'LIMA, Augusto Pinto. Atos políticos. Abusos do Executivo. Supremacia do Poder Judiciário no regime. Revista de Crítica Judiciária, Rio de Janeiro, v. 8, n. 3, set. 1928, p. 162-163. 
estado de sítio e pontua que, cessado esta medida, os direitos individuais lesados deveriam ser tratados exclusivamente ao Congresso Nacional e ao Legislativo, o qual ficaria encarregado das prestações de contas dos interrogatórios e inquéritos abertos, a fim de apurar a responsabilidade dos suspeitos ou envolvidos em perturbações da ordem pública, denotando a preocupação da publicação com a lesa desses direitos.

Questiona-se o dever de reparação pelos danos causados por agentes do Poder Executivo aos cidadãos, visto na publicação na análise do acórdão do Supremo Tribunal Federal sobre a indenização no caso do bombardeio a propriedades privadas pela União com o intuito de combater os insurrectos do Contestado, em Santa Catarina ${ }^{8}$. A Revista vai de encontro à decisão que absolve o governo brasileiro de seus abusos pelo não pagamento de danos, justificando que foi por uma necessidade de interesse público e que as forças federais em operação agiram de acordo com a orientação de seu comandante, porém se critica na publicação que mesmo na lei no caso de guerra ou comoção intestina, ao permitir às autoridades competentes usar da propriedade particular, é de direito ao proprietário a indenização posterior. Por conseguinte, explicita-se certa discricionariedade de determinados julgamentos que absolvem ou condenam sob os mesmos argumentos, denotando o enfraquecimento da ordem jurídica ${ }^{9}$.

Mais um aspecto que tece a crítica da Revista ao Executivo está na possibilidade da intervenção federal nos estados a favor ou contra seu benefício, rejeitando, pois, a hipótese da intervenção ser contra particular ou autoridade inferior, bem como contra

8“No primeiro quartel deste século, a controvérsia a respeito da jurisdição sobre uma vasta região que abrange porções dos territórios atuais do Paraná e de Santa Catarina, provocou uma acirrada disputa entre esses dois Estados. O litígio, cujas origens eram antigas - muito anteriores à República - agravou-se com o estabelecimento do novo regime, em decorrência direta da autonomia constitucional adquirida pelas unidades federativas. O Contestado - essa a designação pela qual veio a ser conhecida a região - foi então palco de conflitos armados localizados, de maior ou menor importância, sendo que, ao mesmo tempo, a questão dos limites veio a ser objeto de discussões e deliberações nas mais altas cortes judiciárias do país". MONTEIRO, Duglas Teixeira. Um confronto entre Juazeiro, Canudos e Contestado. In: O Brasil republicano, v. 2: sociedade e instituições (1889-1930) In: FAUSTO, Boris. (Org.) História Geral da Civilização Brasileira. Rio de Janeiro: Bertrand Brasil, 2004, p. 71. Ver também: QUEIROZ, Maurício Vinhas de. Messianismo e Conflito Social, A Guerra Sertaneja do Contestado - 1912-1916. Rio de Janeiro: Civilização Brasileira, 1966.

9 "Por isso mesmo, no acórdão de 10 de agosto de 1932, relator o Ministro Laudo de Camargo, unanimemente mandou a Turma Julgadora ressarcir a um particular, pela União, o dano sofrido em consequência do bombardeio da cidade de S. Salvador, em 1912, realizado imprudentemente pela força federal, para o cumprimento de uma sentença judiciária. Pode-se, pois, considerar assente agora no Supremo Tribunal Federal o bom princípio de que as pessoas jurídicas de direito público respondem pelos atos, mesmo dolosos ou criminosos, dos seus funcionários, lesivos de direitos de terceiros, desde que por eles praticados em tal qualidade, como acentuou o Ministro Espinola no seu voto por ocasião do recentíssimo julgado de 2 de junho de 1933, objeto especial deste comentário, e cuja ementa traduz fielmente a doutrina vencedora”. FONSECA, Arnoldo Medeiros de. Supremo Tribunal Federal. Revista de Crítica Judiciária, Rio de Janeiro, v. 18, n. 4, out. 1933, p. 268. 
os municípios. O voto de Hermenegildo de Barros, em 15 de abril de 1935, não conheceu o pedido do juiz federal da Bahia de requisição da intervenção do Presidente da República à Corte Suprema a fim de executar ordens e decisões dos juízes e tribunais federais, visto que a intervenção foi solicitada contra ato de desobediência um engenheiro da ferrovia, o qual não seria sequer uma autoridade, à ordem de reintegração de posse, descumprindo a ordem federal (VAMPRÉ, 1935). Além disso, Barros referenda que a intervenção somente se concederia quando as autoridades estaduais ou municipais recusam ou impedem a execução da sentença federal, o que não ocorrera. Nota-se pela publicação que os textos constitucionais não se referem a autoridades municipais, nem à intervenção federal em município, ou contra autoridade municipal, uma vez que essa possibilidade teria sido excluída pelo legislador constitucional, pela razão simples de que a organização municipal resultaria da lei estadual, refletindo, assim, a conformidade do voto com a disposição constitucional.

E quanto à responsabilização civil do Presidente da República, no tocante ao efeito regressivo da condenação do dano causado pela União?

A partir do parecer ex- Procurador da República, Carlos Maximiliano, a Revista de Crítica Judiciária vai de encontro a ele e desempenha sua crítica ao considerar válida a responsabilidade civil dos governantes do país, visto a urgência de firmar e definir as conquistas liberais da democracia à época no Brasil" ${ }^{10}$. Todavia, há notáveis reflexões no parecer de Maximiliano sobre o enquadramento do cargo de Presidente da República, em termos do direito administrativo, se ele seria ou não um funcionário público e quais as suas atribuições decorrentes desta definição a fim de responsabilizá-lo ou não pelos atos da União. Traz o então Procurador referências do direito italiano, a saber, Francesco D'Alessio e sua obra Institizionidi Diritio Amministrativo, na qual considera funcionário público aquele preposto às suas funções por um ato especial da administração, não se enquadrando, assim, o cargo de Presidente, do direito francês, Gaston Jéze e sua obra Les Principes Géneraux Du Droit Administratif, na qual distingue os funcionários e agentes públicos dos governantes, respaldando ainda mais a tese de Maximiliano afirmadora de um conceito ímpar ao encargo

10 "Se o Chefe do Governo demitisse, por exemplo, todos os juízes federais do país e os mesmos promovessem nos Estados as necessárias ações de reparação, deveria o causador à ofensa daqueles direitos deixar de ser citado também, correndo unicamente por conta do Tesouro as consequências do arbítrio administrativo? Reputamos nociva aos interesses públicos a doutrina que preconize esse resultado. O brilhante parecer transcrito não o diz claramente, mas o analista chega logicamente a essa conclusão." VASCONCELLOS, Nilo C. L. de. Presidente da República. Revista de Crítica Judiciária, Rio de Janeiro, v. 24, n. 4, out.1936, p. 325326. 
do Presidente da República (VASCONCELLOS, 1936). Além disso, rememora o elemento histórico ao adentrar nos conceitos atribuídos a funcionário público na Comissão do anteprojeto do Código Civil, bem como da Constituinte.

Contraponto tais argumentos de Maximiliano, a Revista coaduna o dispositivo constitucional de 1891, no qual os funcionários públicos seriam restritamente responsáveis pelos abusos e omissões em que incorrem no exercício dos seus cargos, o dispositivo do Código Civil de 1916, no qual as pessoas jurídicas de direito público seriam civilmente responsáveis por atos de seus representantes, e o dispositivo da Constituição de 1934, no qual não haveria distinção entre funcionário e representante do poder público (VASCONCELLOS, 1936). Acrescenta-se a colocação de Clóvis Bevilaqua, que nos danos causados por atos da administração pública, a responsabilidade não poderia ser desviada, uma vez que ela agiria por intermédio de seus órgãos, a de Spencer Vampré, que o Presidente da República seria um funcionário eletivo, e a de Themistocles Cavalcanti em seu trabalho sobre direito administrativo, que não poderia se negar ao Presidente da República a qualidade de funcionário no seu sentido mais genérico. E, para fins dos moldes do sistema liberal democrático de governo, vê-se nos Estados Unidos e suas funções administrativas o Presidente da República como um funcionário político.

\section{O USO DO LEGALISMO NO COMBATE AOS MOVIMENTOS SOCIAIS}

A formulação e votação de leis em um tempo repleto de agitações sociais e políticas foi um desafio imposto às comissões legislativas na Primeira República. O impasse da legislação acerca do habeas-corpus é um exemplo, de um lado a comissão nomeada pelo Governo Provisório, da então instaurada República, a fim de organizar um anteprojeto de Constituição, tem-se no habeas-corpus o remédio contra a ilegalidade e o abuso de poder frente a violência e à coação de direito individual. De outro há a Comissão do Congresso que propusera que o indivíduo que sofre ou se achar em iminente perigo de sofrer a violência ou coação, por ilegalidade ou abuso de poder, se pode usar desse remédio, um conceito, dessa forma, mais amplo, que vai de encontro às disposições legislativas do império, as quais se 
falavam em prisão ilegal e constrangimento ilegal, restringindo a liberdade individual, mais precisamente a liberdade física $^{11}$.

O excessivo alcance dado pelo Poder Legislativo gera frutos na jurisprudência dos tribunais, inclusive estendendo à proteção de situações políticas. Critica-se na Revista de Crítica Judiciária o surgimento de votos transformados em dissertações jurídicas a fim de salvaguardar interesses governamentais. Dá-se como exemplo o caso de Pedro Lessa, o qual justificara sua atitude e da maioria dos seus colegas ao afirmar que os habeas-corpus assecuratórios de situações políticas se garantia o jus ambulandi, a liberdade física. Assim, ao conceder um habeas-corpus a um conselheiro municipal ou a um deputado estadual devidamente eleito e reconhecido, o Tribunal somente intenta o exercício de tal mandato à medida que garante a faculdade de tal indivíduo de se dirigir livremente, sem constrangimentos ao lugar que é destinado às suas funções ${ }^{12}$.

As incertezas legislativas não cessaram posta a Revolução de 30, as escassas iniciativas de estabelecer uma Constituição para o país fez com que a Revista de Crítica Judiciária criasse uma enquete entre os juristas se seria oportuna ou não a instauração de uma Constituinte. Inicia-se a discussão pelo diretor Des. Vieira Ferreira, o qual questiona como poderia formar uma Constituinte diante um sistema eleitoral ainda inadequado, vista a eleição de representantes pouco confiáveis, principalmente, na representação de uma autoridade moral (FERREIRA, 1931). Astolpho Rezende denuncia que até o advento do Governo Provisório o país vivia uma ditadura irresponsável, residindo todo o poder no Presidente da República, as quais eram reforçadas as aparências de legalidade deste governo (REZENDE, 1931).

Enfatiza-se a lei como autoridade legítima frente a inaptidão da eleição popular dos membros do poder legislativo a fim de formar a soberania nacional e conservar a ordem

11 "Doutrinando no Senado, na sessão de 22 de janeiro de 1915, Ruy Barbosa, ensinava, depois de citar o parágrafo 22 do art. 72 da Constituição, que ora se pretende emendar, e que muitas vezes já se tem pretendido sofismar: "Não se fala em prisão, não se fala em constrangimento corporal. Fala-se amplamente, indeterminadamente, absolutamente, em coação e violência, de modo que onde quer que se manifeste a violência e a coação, ahi está estabelecido o caso constitucional do habeas-corpus"”.". MORAIS, Evaristo de. A reforma constitucional e a restrição do habeas-corpus. Revista de Crítica Judiciária, Rio de Janeiro, v. 2, n. 5, nov. 1925 , p.481.

12"Referindo-se, exatamente, aos habeas-corpus concedidos aos juízes do Tribunal do Amazonas e aos conselheiros municipais da Capital Federal e combatendo a doutrina do ministro-professor Pedro Lessa, dizia Ruy Barbosa no Senado: - "E levar muito longe a elasticidade das ficções e coloca-las assim em contradição com a realidade". E perguntava: - "Pois não foi o Supremo Tribunal Federal quem me concedeu a mim, como membro desta Casa, o direito de assegurar a publicação do meu discurso, bem como a publicação dos discursos de todos os membros do Congresso Nacional na imprensa brasileira? Foi ao constrangimento corporal que se acudiu neste caso?"”. (MORAIS, 1925, p.484). 
social (LIMA, 1931). O anseio por uma sistematização das funções de mando, das atribuições de disciplina pelo aspecto positivo das necessidades sociais de equilíbrio e organização do país alicerça a contrariedade diante de um governo arbitrário, o qual não se constitui pela harmonia entre os poderes e suas esferas de interesse, os chamados freios e contrapesos constitucionais.

Levi Carneiro, então consultor geral da República, a quem o Governo Provisório, atribuíra a direção dos trabalhos de reorganização da lei constitucional à época, analisa ser necessário um estudo preliminar à Constituinte realizado por uma Comissão Legislativa, visto que ainda cabe ao Poder Legislativo reestruturar-se, principalmente, o Congresso Nacional. Este ente democrático ainda repleto de defeitos e vícios far-se-ia uma mesma emenda legislativa de outrora, desprestigiando o poder que o segue por seguir os passos de uma substituição. Desse modo, a Revista pontua que uma Constituição deve resultar de uma obra de reorganização política e jurídica, não se tratando da mera substituição de indivíduos em cargos políticos (CARNEIRO, 1931).

A noção de serviço público é trazida à publicação a fim de construir um interesse comum, destacando as índoles moral e social, bem como a aparelhagem secundária, remodelada nos órgãos administrativos e na lei eleitoral. A Comissão Legislativa dirigida por Carneiro passa pelo aprimoramento da função legislativa estatal e não pela transmissão da mesma, preservando a tarefa democrática de elaboração das leis. Frente as múltiplas determinações constitucionais da Constituição de 1891, viu-se o enrijecimento dos julgamentos para reconhecer exceções, a saber, o artigo que tratava das acumulações remuneradas e do direito de propriedade, gerando um anseio de compor uma legislação constitucional nacional mais concisa que a anterior, a qual refletiria os questionamentos do então governo.

O pedido de delimitação do poder, necessária a independência e a liberdade individual, são recorrentes nas opiniões arrecadadas na enquete da Revista de Crítica Judiciária a fim de consolidar uma nova fase republicana brasileira, a qual não logrou êxito com o advento do governo Vargas (REICHARDT, 1931). Retrata-se a urgência da convocação de uma Constituinte, inclusive pelo Governo Provisório que na Lei Orgânica de 11 de novembro de 1930, estatuiu-se que no art. 12, a nova Constituição Federal mantivesse a forma republicana federativa e não poderia, assim, restringir os direitos dos municípios e dos 
cidadãos e suas garantias individuais constantes da Constituição de 1891. Esse apelo foi igualmente emanado pelo Instituto da Ordem dos Advogados ${ }^{13}$.

Uma lei eleitoral prévia de molde a assegurar não só a liberdade do sufrágio, mas, o sufrágio contra a fraude dos poderes a que se entregam a apuração e o reconhecimento final dos mandatos eletivos, uma reeducação popular por meio da punição das fraudes eleitorais e uma seleção de novas mentalidades são imprescindíveis à instituição da Constituinte. As incertezas nesse vácuo legislativo nacional em um período transitório do país envolveram todos os âmbitos dos poderes ao se comparar com o regime iniciado em 1891, um substituto fiel à monarquia (JORDÃO, 1931). O modus operandi para criação do Estado de Direito brasileiro do Governo Provisório de 1930 seria similar ao do Governo Provisório de 1889, denuncia a Revista.

Entende-se a convocação da Constituinte em 1930 atrelada à condição da revisão política e dos representantes do Poder Legislativo pelo intuito de se diferenciar dos mandatários anteriores à revolução, que, no entanto, à época ainda continuaram presentes em seus cargos (KELLY, 1931). A certeza da fase democrática e da educação cívica seria alcançada com real espaço para uma manifestação livre da vontade popular, que preceitua a decretação de uma lei eleitoral confiável a um regime democrático. Entretanto, não seria o caso brasileiro no período, o qual ainda pendente a uma ditadura vista a falta de convicções republicanas e o mito do sufrágio popular da Primeira República ${ }^{14}$.

A Revista de Crítica Judiciária no encalço da instalação de um regime democrática registra o parecer de todos os membros do Instituto da Ordem dos Advogados, o qual pede ao chefe do Governo Provisório da época, Getúlio Vargas, a convocação da Constituinte a fim de não perpetuar o tempo ditatorial nesse ínterim (CUNHA, 1931). Ademais, Clovis Bevilaqua formula perguntas acerca da futura ordem constitucional brasileira e as responde, dentre elas, sobre a representação por classe e em que caráter e com que amplitude deveria ser aplicável e outra no que tange a função social da propriedade (BEVILAQUA, 1931). É curioso esse cuidado que a publicação obedece em delimitar as

13 JORDÃO, Edmundo de Miranda. É oportuna a Constituinte? Revista de Crítica Judiciária, Rio de Janeiro, v. 13, n. 5, mai. 1931, p. 316.

14 "A ditadura deverá permanecer enquanto não se modificar a mentalidade política, convencendo-se a Nação, pela experiência e confronto, de que o regime parlamentar nada mais representa do que uma ditadura oculta e irresponsável. O sufrágio popular é mistificação. Uma constituinte seria o produto desse sufrágio". REZENDE, Octavio Murgel de. É oportuna a Constituinte? Revista de Crítica Judiciária, Rio de Janeiro, v. 13, n. 6, jun. 1931, p. 396. 
perspectivas políticas do estado brasileiro, que cumpriria o resguardo dos direitos das classes mais numerosas sem configurar um regime socialista, bem como o resguardo do direito da propriedade limitada pelo direito individual.

A dúvida de sobre qual Constituição estaria em vigor é recorrente nesse tempo do Governo Provisório e a Revista esclarece através da consulta a seus juristas colaboradores, dentre eles o consultor geral da República, Levi Carneiro, o qual diz que a Constituição de 1891 ainda estaria em vigor (ASSIS, 1933). No entanto, destaca Carneiro que a Constituição se tornara flexível e, por sua vez, suscetível de modificações pelas próprias leis ordinárias emanadas pelo próprio governo. Outro complemento desse esclarecimento vem de Astolpho Rezende, o qual fora investido das funções do poder legislativo e denotando sua autoridade de dizer sobre a lei, que ao responder Assis Brasil e seus pontos de vista dos partidos políticos do Rio Grande do Sul, dentre os quais salientava a necessidade de vigorar partes referentes à declaração de direitos da Constituição de 1891, expõe o decreto n. 19.398 de novembro de 1930. Tal decreto mantivera em vigor os artigos constitucionais que estabeleciam as restrições necessárias à ação governamental, bem como manteve todos os direitos e todas as disposições limitavam o poder indispensável ao governo de fato.

Em nova publicação, a Revista realiza um compêndio de quais princípios deveriam estar presente na nova Constituição, a exemplo, das pretensões do Poder Judiciário como a unificação da magistratura e sua organização independente da interferência de outros poderes (LIMA, 1933). Há princípios que objetivam aspectos de formação de uma brasilidade, como a proibição da existência de escolas estrangeiras e nacionalização dos bancos, minas, águas e estradas de ferro. Outros reafirmam a pauta da Revista sobre a concessão de habeas-corpus sempre que o indivíduo sofrer ou se achar em iminente perigo de sofrer violência, ou coação, por ilegalidade, ou abuso de poder, desse modo configurando uma defesa de qualquer direito líquido e certo e a favor dos pronunciados e condenados em processos evidentemente nulos, por exemplo.

A demanda acerca da unidade do processo é em igual medida referenciada na Revista ao se examinar os discursos pronunciados pelos deputados naquele tempo, Daniel de Carvalho e José Ferreira de Souza (REVISTA, 1934). Carvalho inicia seus argumentos em prol da unidade processual ao refutar, em plenário da Assembleia Constituinte de 1934, a substituição dessa unidade pelo simples artigo constitucional que conferiria à União competência privativa para legislar sobre as normas fundamentais do processo e polemiza ao 
concluir que não há, por sua vez, alguma definição de quais seriam essas normas, estabelecendo, definitivamente, uma vagueza conceitual no direito processual. Defende, ainda, que a unidade do processo vem conjuntamente com a universalização do direito, relembrando a polêmica entre João Mendes e Pedro Lessa sobre a questão metafísica da forma e da substância e sobre a questão jurídica da descriminação entre o direito substantivo ou material e o direito adjetivo ou formal, a fim de ilustrar que a multiplicidade de códigos processuais compromete a unidade do direito.

Adentra-se, nesse entrave consubstanciado em Assembleia, na formação de um critério mais seguro para orientar a ação legislativa e para resolver as questões jurídicas apresentadas nas controvérsias, como a unidade processual, da doutrina e da prática sobre a natureza substantiva ou adjetiva de certas normas. O problema admite Carvalho está na dualidade jurídica instaurada em 1891, aquém de construir uma unidade entre os tribunais vista no tempo imperial, criando impedimentos entre as diversidades regionais e o regime uno federal. Esse tema foi de grande repercussão que na segunda Conferência de História Nacional promovido pelo Instituto Histórico Brasileiro, em março de 1931, aprovara a tese do Des. André Pereira, pugnando pela restauração da unidade da legislação processual, bem como comissões organizadas no seio do Instituto dos Advogados do Brasil para estudar a matéria.

O deputado Ferreira de Souza, na emenda vitoriosa na Constituinte, justifica a unidade do direito e do processo, em virtude da federação vista como um movimento de solidarização, de integração, de junção num todo único, só ele soberano e superiormente forte (REVISTA, 1934). Destaca, ainda, que a dualidade foi imposta aos entes jurídicos e aos estados federados, o qual se demonstrara pela semelhança dos códigos processuais dos mesmos, como verdadeiras cópias, sem qualquer preservação de características regionais que poderiam vir a serem contrárias a uma diretriz processual nacional única.

\section{CENTRALIDADE E ATIVISMO DO JUDICIÁRIO}

Em um cenário brasileiro de incertezas do início do século $\mathrm{XX}$, fez-se necessário à Revista de Crítica Judiciária alicerçar os pilares para uma centralização do Poder Judiciário. Diante de um federalismo apregoado pela Primeira República, viu-se uma 
instabilidade política por parte do poder central, deslegitimando, muitas vezes, a magistratura em suas esferas ${ }^{15}$. Desse modo, o impeachment é trazido ao estudo na Revista pela análise do projeto apresentado em 1911, pelo então senador João Luiz Alves, diante das clavas de Ruy Barbosa e Pedro Lessa.

Tal documento parlamentar é evocado na publicação por seu método de explanação concisa, pela perquisição do jurista à fonte de origem do instituto jurídico, bem como escavar o cerne do direito constitucional a fim de buscar uma possível aplicação desse meio em âmbito nacional. O impeachment dos Ministros do Supremo Tribunal Federal, como posto à Constituição de 1824, possui especial atenção do autor do projeto por ser uma penumbra na legislação, principalmente diante da diversidade de opiniões suscitadas à época. O projeto estuda quatro questões: se todo o processo, desde a queixa ou denúncia, deveria correr perante o Senado ou a este só competia o julgamento; se as normas processuais deveriam ser estabelecidas em lei ou no Regimento Interno do Senado; se deveria ser definidos em lei especial os crimes de responsabilidade dos Ministros do Supremo Tribunal Federal ou tais crimes deveriam ser os mesmos delitos funcionais definidos no Código Penal; e se poderia ser iniciado o processo e quais as normas processuais que deveriam ser adotadas (VASCONCELLOS, 1925).

No que tange a primeira questão, o autor do projeto utiliza-se das constituições argentinas e americanas, logo concluiu que a parte das duas na constituição pátria quanto da procedência da Câmara para receber ou não a denúncia contra o Presidente da República e Ministros de Estado, nos crimes conexos com os daquele, afastando, porém, a competência quantos aos Ministros do Supremo Tribunal Federal, à vista do silêncio da Constituição. Adianta-se a crítica da Revista, a dizer que este silêncio não pode ser interpretado como um lapso do legislador constituinte, em matéria de tal relevância, visto que há impossibilidade do uso da interpretação extensiva ao caso. Desse modo, o autor do projeto opina por negar à Câmara o direito de receber a queixa ou a denúncia, para transferir as armas e bagagens, para o Senado, na sua dupla função de acusar e julgar"(VASCONCELLOS, 1925).

15 "Entregue ao arbitrio dos poderes locaes a magistratura baixou, moral e profissionalmente, porque os magistrados estaduais não tem horizonte. As suas funções mal retribuídas, a sua carreira confinada, a sua estabilidade precária excluem, em geral, do seu quadro, as melhores capacidades. Moralmente, porque, abandonada aos interesses da Província, às suas revoluções, às intolerâncias dos seus partidos, a magistratura local tem de acabar resignada ao papel de instrumento político e vegetar nessa condição desmoralizadora". BARBOSA, Ruy. In: RODRIGUES, José Martins. A Unidade da Justiça e a organização constitucional. Revista de Crítica Judiciária, Rio de Janeiro, v. 14, n.1, jul. 1931, p. 4. 
Sobre a segunda questão, tem-se a opinião de João Luiz Alves, respaldada pela Constituição de então, que ninguém seria sentenciado senão pela autoridade competente em virtude de lei anterior e na forma por ela regulada. A terceira questão é o ponto visceral do projeto, o autor enumera quais os crimes de responsabilidade e faz sua análise, precisando, assim, os únicos motivos que justificariam o impeachment dos Ministros. Nesse ponto, igualmente, é abordado pela crítica da Revista, visto que evoca a questão política deste projeto, que de um lado está entregue o Supremo Tribunal a competência de declarar inconstitucionais e ilegais as leis do Congresso e os atos do Executivo atentatórios dos direitos individuais, sendo curial, segundo a crítica, se admitir a existência de outro poder que venha a ter intromissão em tais atos, julgando-os e entrando no mérito deles, desde que privativos do Tribunal que os proferiu, no exercício de sua função (VASCONCELLOS, 1925).

As demais questões são analisadas pelo autor do projeto sob o prisma de quem poderia denunciar os abusos de direito dos Ministros do Supremo Tribunal e promover sua responsabilização. Ao abrir espaço para um estudo de tais questões sobre o Poder Judiciário, a Revista buscou oportunizar uma reflexão sobre as instituições pátrias, bem como fomentar o debate sobre a reforma constitucional que viria, complementando-o com o choque de opiniões opostas (VASCONCELLOS, 1925).

No período presidencial de Arthur Bernardes, marcado pela decretação do estado de sítio, conflagra inúmeros debates entre os poderes acerca dos direitos individuais e sua defesa e o instituto do habeas-corpus. O caso debatido à Revista é o habeas-corpus impetrado por Ruy Barbosa em defesa do paciente José Eduardo Macedo Soares, então diretor do jornal $O$ Imparcial, o qual foi detido e ficou incomunicável em sede da Brigada Policial à época (REVISTA, 1925). Admite-se a ineficácia dos atos legislativos e do Executivo, quando violadores do direito individual, por meio de ação judicial, visto que o Poder Judiciário projeta sua ação apenas para fazer cessar efeitos da medida governamental que o estado de sítio, segundo então Constituição, não poderia produzir.

Quanto à detenção por motivos políticos ou desterro dentro do território do país, são permitidos no sítio, contudo, esclarece-se que nenhuma violência pode pesar sobre os detidos ou desterrados, segundo crítica da publicação. Assim, no caso estudado, a incomunicabilidade do paciente é um excesso de defesa da ordem social, arbítrio que o sítio não autoriza, configurando um abuso de poder, coação francamente ilegal, para o qual o habeas-corpus seria o remédio próprio. Ademais, atesta-se que a faculdade do Tribunal de 
declarar inconstitucionais as leis votadas pelo Poder Legislativo e sancionadas pelo Executivo, também se aplica à decretação de sítio, quer tenha a iniciativa da medida o Congresso, quer o presidente da República, com a aprovação posterior do Congresso, visto que a decretação dessa medida pelo Poder Executivo é sempre eivada de suspeita de ilegalidade e violência ${ }^{16}$.

Mais um aspecto que se trata da fragilidade da magistratura nos conflituosos anos 20, é a inamovibilidade dos magistrados, a qual é retrata no estudo da Revista de habeascorpus contra a remoção de juiz de direito, Dr. Aristides Sicca, da Comarca de Cassia, Minas Gerais (FERREIRA, 1925). Apesar das constituições e leis estaduais, há prevalência dos princípios constitucionais da União, dentre eles a independência dos poderes entre si, que no caso em tela, o ato do governo mineiro contrariara tal disposição. Por conseguinte, a independência do Poder Judiciário baseia-se nos princípios da vitaliciedade, da inamovibilidade e da irredutibilidade dos vencimentos, conferidos pela constituição à época.

O poder judicial não seria propriamente político, porém é um órgão da soberania no que tange a organização política do país, ressaltando, na crítica exposta na publicação, que o juiz que se faz instrumento político desvirtua sua função. Apregoa-se, assim, a necessária sujeição da política ao direito a fim de adquirir uma estabilidade interna, visto que a resolução dos conflitos é regulada por texto legal que o Poder Judiciário declara aplicável ao caso concreto. Confirma-se, mais uma vez à época, o habeas-corpus como meio de proteção de direito individual ao invés de aparelho regulador de direito público.

A constitucionalidade de recurso judiciário durante as eleições municipais é mais um debate instaurado na Revista de Crítica Judiciária frente ao federalismo exacerbado na Primeira República. O candidato a prefeito do município de Petrópolis, do Estado do Rio de Janeiro, em 1928, com fundamento em lei estadual interpôs recurso ao Tribunal de Relação contra ato da Câmara Municipal que reconheceu o seu competidor prefeito por votos válidos (FERREIRA, 1928). Ao ser negado tal pedido e anulada as eleições municipais, o candidato a prefeito ingressa com recurso extraordinário alegando que o Tribunal violara os preceitos de autonomia dos municípios, uma vez que há a lei orgânica municipal.

16 “A ordem de soltura de um preso político não quer dizer um bill de indemnidade. Não é uma carta de corso. Não é um habeas-corpus contra um dos poderes constitucionais. Pelo contrário, é o reconhecimento do sagrado direito individual, que a sentença restabelece. É a condenação do ato prepotente, do abuso de poder, da coação, da violência sofridos pelo paciente, na liberdade e no patrimônio moral.” LIMA, Augusto Pinto. O Executivo e o sítio. Supremacia do Judiciário. Revista de Crítica Judiciária, Rio de Janeiro, v. 4, n.2, ago. 1926, p. 135. 
Não obstante, a autonomia municipal é limitada à época. Os estados teriam a competência de organizar os seus municípios, consoante, crítica da publicação ao recurso, inclusive, lembrando que a instituição do recurso judiciário decorre direta e imediatamente da atribuição dada pela então Constituição Federal aos estados. Portanto, é interdito tal recurso, segundo disposição constitucional, contra a intervenção nos estados, contra a declaração do estado de sítio e contra a verificação e reconhecimento de poderes dos membros dos Poderes Legislativo ou Executivo, federal ou estadual.

Ingressa-se no tema do federalismo como criação jurídica, não resultante de um processo histórico-social, o qual se debate a dualidade do poder judiciário brasileiro na Constituinte da Primeira República. A construção da pluralidade da magistratura esbarra nos estreitos limites de cada estado da federação, cortando o acesso aos tribunais federais. A publicação traz a discussão que se travou no plenário da Constituinte entre o ministro da Justiça, de um lado, secundado por Leopoldo de Bulhões, Justiniano de Serpa, Augusto de Freitas, Gonçalves Chaves, J. J. Sebra, Angelo Pinheiro, Americo Lobo, Lauro Sodré e outros; e, do outro lado, José Hygino, Amphilophio, defensor da unidade da justiça, Badaró, partidário da independência dos tribunais superiores para emendar e corrigir os erros dos juízes de primeira instância (RODRIGUES, 1931).

Contudo, em projeto apresentado à convenção nacional pelo Governo Provisório, consignava-se aos estados que estes não poderiam se organizar sem obedecer a determinadas regras, principalmente as que concerniam à organização do Poder Judiciário, a saber, a não eleição da magistratura estadual, bem como a não demissão dos magistrados, a não ser por sentença judicial. Tais concepções do projeto não foram adotadas no texto definitivo, apesar de na jurisprudência serem consolidadas como princípios constitucionais, dentre os quais, a vitaliciedade, a inamovibilidade e a irredutibilidade dos vencimentos dos juízes estaduais, consoante se expõem na Revista.

Novamente a duplicação do judiciário, em federal e estadual, é estabelecida em reforma ocorrida em 1926, defendida por Pedro Lessa, o qual considera esta modificação inerente à organização constitucional federativa, bem como seus partidários Carlos Maximiliano e Levy Carneiro. Os debates contra essa mudança são, do mesmo modo, retratados na Revista através da defesa da unidade da administração da justiça defendida por Amaro Cavalcanti e José Hygino (RODRIGUES, 1931). Ademais, em campanha política em 1910, Ruy Barbosa foi veemente contrário à dicotomia judiciária, aconselhando em sua 
plataforma a revisão constitucional a fim de unificar o direito processual e a magistratura e conferir aos tribunais superiores segurança e garantia diante dos outros poderes ${ }^{17}$.

Diante de uma revolução feita em outubro de 1930, a Revista faz sua crítica sobre a Aliança Liberal estabelecida e sobre quais os conjuntos de princípios que ela adotaria para eliminar os problemas da organização judiciária brasileira à época, ressalvando os fundamentos da estrutura política do país de Oliveira Vianna e outros juristas que passam pela resolução do problema da liberdade política e da liberdade individual ao se tratar da descentralização do Poder Judiciário. Atenta-se que o programa da Aliança Liberal e a plataforma política do seu candidato não se referiam aos quaisquer princípios que assegurem a independência da magistratura. Tem-se apenas o trabalho de Juarez Tavora que trata não da unidade, mas de uma uniformização do Poder Judiciário ${ }^{18}$.

O clima de instabilidade do Governo Provisório instaura-se e a Revista de Crítica Judiciária evoca, em primeira página de sua edição de maio de 1932, a ordem jurídica e o sentimento de brasilidade a fim de driblar o caos (VASCONCELLOS, 1932). Entende-se pela ordem jurídica, a segurança dada pelo Direito, sendo ele soberano juntamente da justiça, uma vez que ele substitui a força, necessário há um regime civil, consequentemente, necessário ao Estado brasileiro. Já a brasilidade é trazida a fim de emoldurar a unidade nacional buscada pelos poderes e pelas instituições à época, dentre eles, o Poder Judiciário.

Essa brasilidade retrata-se na Revista ao disponibilizar espaço a fim de prestigiar os magistrados atuantes da Justiça do Acre, então território federal em 1933. Enaltece-se a magistratura nacional e o seu papel desbravador aos sertões do país através da ideia de independência e de liberdade patriótica alicerçada pelos bacharéis desde Coimbra, refletindo a força e a cultura jurídica brasileira. A Justiça do território foi lembrada ao passo da publicação de suas decisões entre os anos 1923 a 1926, pelo presidente de seu tribunal o

\footnotetext{
17 Disse Ruy Barbosa: “- Os mesmos preceitos legislativos passam, em vinte e uma judicaturas autônomas, por outras tantas aplicações dissidentes, degenerando a jurisprudência, num aglomerado caótico de antagonismos irredutiveis, por falta de uma autoridade comum que os elimine". Para logo, fulminar desta forma o sistema dual da Constituição de fevereiro, mostrando, como já fizera Amaro Cavalcanti, como ele contribuiu para entregar a justiça aos apetites desenfreados da politicalha local, degradando-a moral e profissionalmente. (RODRIGUES, 1931)

18 "Por outro lado, o que a pratica da revolução vai demonstrando longe está de tender para a unidade da justiça. Apesar de se tratar de um governo ditatorial com delegados seus nos Estados, não há a menor uniformidade de ação a respeito da magistratura, cada interventor se julgando no direito de ir além do procedimento do poder central, investindo violentamente contra as mais elementares e precárias garantias do judiciário, que, desprovido hoje de todas as parcelas de autonomia e independência, está reduzindo à situação de mera subdivisão do poder executivo e a este integralmente subordinado."(RODRIGUES, 1931)
} 
Des. Antonio Cesario de Faria Alvim Filho, reconhecida pelo seu adequado exercício legal e justo.

Mais um entrave é posto ao Governo Provisório, no que tange a reformulação do direito nacional e do Poder Judiciário, apesar de suas tentativas sem êxito de suas Comissões Legislativas e da Comissão de Reorganização da Justiça, as quais foram providenciadas pelo senso construtivo e visão objetiva dos revolucionários. Todavia, a obsessão do federalismo, denunciada em crítica pela Revista, reponta nas entrelinhas do anteprojeto de reforma judiciária, inclusive uma intolerância religiosa dos grandes estados ${ }^{19}$. Desse modo, constata-se um espírito retardatário da reforma ao salvaguardarem-se as influências políticas dos estados e ao garantir interesses das classes, no apego às doutrinas do individualismo, dos três poderes e da soberania de uma sociedade da força bruta do mandonismo e do cangaço (NOBREGA, 1933).

\section{CONSIDERAÇÕES FINAIS}

Mais uma vez, a Revista trata de condenações criminais, de cunho político, feitas a posteriori pelo poder judiciário de atores de movimentos revolucionários no início da década de 1920 a fim de mostrar que a ilegalidade destas e alertar para o enfraquecimento da unidade nacional pelo clima de insegurança jurídico causado. Cobra-se, por parte da publicação, assim, dos revolucionários de 30, o cumprimento em seu programa político uma completa unificação da justiça, com independência real, unicidade da lei processual, instrução primaria e profissional obrigatória, equitativa divisão dos estados, igualdade territorial o quanto possível fosse, substituição do Congresso por comissões técnicas eleitas e a instituição de um Conselho de Estado vitalício ${ }^{20}$. Esse Conselho defendido, aos moldes de Oliveira

19 "Continua-se no velho sestro de legislar "para a rua do Ouvidor", de olhos fitos nos "grandes Estados" Rio Grande do Sul, Minas, S. Paulo, Distrito Federal, cujas condições privilegiadas tem propiciado um nível cultural mais elevado, um standard de vida socialmente mais perfeito". NOBREGA, J. Flóscolo da. À margem do anteprojeto de reforma da Justiça. Revista de Crítica Judiciária, Rio de Janeiro, v. 18, n. 4, out. 1933, p. 255.

20Veja: "Essa unificação da Justiça é reclamada por todos aquelles que cedo sentiram na sua falta um dos maiores defeitos do Regime, mas para sua conquista não é necessária à difamação oficial - felizmente apenas verificada em Pernambuco - contra o poder judiciário, dos três poderes constitucionais justamente o único que se salvava da falência das instituições republicanas, e que por sua constante resistência aos desmandos dos outros poderes, tanto os da União como os dos Estados, era ainda um freio a maiores demasias dos governantes e único abrigo a que o povo recorria confiante na defesa dos seus direitos. É um crime contra os créditos morais 
Vianna na sua Política Objetiva, não teria atribuições apenas de Poder Moderador, mas ainda coordenaria as leis, visando à continuidade administrativa, em termos econômicos e morais, do país.

Em termos de política internacional à época da Revista, surge o contraponto ao sistema mundial econômico vigente, por conseguinte, ideológico e político, que seria o socialismo, a partir da Revolução Bolchevique. Abriu-se espaço na Revista de discussão do direito soviético, a fim de pontuar, criticamente, suas intersecções e divergências ao direito brasileiro. Constata-se que o direito soviético corporificou as consequências lógicas do pensamento jurídico moderno a fim de levar essas mesmas sociedades para uma renovação, por transição e por estágios de suas fundações legais, visto que arranca do pátrio poder o seu exercício abusivo, não precisando caracterizar castigos imoderados para tanto ${ }^{21}$.

Já dizia Cícero, quando as providências legais não podem acudir o cidadão, devem calar-se as leis e devem deixar ao cidadão o recurso às armas. Fixa-se, dessa forma, o estudo à Revista do direito de revolução que evidencia o Brasil como solo fértil para exercêlo, seja pelos agravos sociais insolúveis de tanto tempo, seja por ser um país novo dentro de um continente igualmente novo ${ }^{22}$. Esse direito é dividido em resistência passiva, resistência ativa legal, rebelião (ofensiva ativa) e resistência ativa armada, bem como se expõem as condições de o povo visar o bem comum, a legítima defesa própria, a última solução, dentre outras. Por conseguinte, ao explanar sobre a revolução e seu direito compreendem-se os seus fatores de origem, evidenciando, assim, a publicação sua tentativa de auxílio aos arranjos críticos de seus leitores a fim de que estes busquem alicerces seguros de soluções ao país.

do pais imputar à sua magistratura faltas ou vícios que só podem e devem ser atribuídos a sua defeituosa organização. Vencedora a Revolução, imprescindível é agora que esse defeito se corrija com um Poder Judicial uno e realmente independente, para que se justifique a imagem feliz da espinha dorsal”. PEREIRA, Eurico de Sá. Direitos políticos - Juízo privativo do direito de cidadania. Revista de Crítica Judiciária, Rio de Janeiro, v. 13, n.1, jan. 1931, p.11.

21 Veja: "E porque a historia russa registe tantos exemplos de que a servicia gera nas almas viris o espirito de revolta, é que os legisladores sovietistas não ficaram no meio termo dessa legislação amorfa, desvirtualisando e desvirilizando do mundo ocidental. Foram radicais! O pai, como o Tzar, não pode exercer um poder abusivo." SIMAS, Hugo. O pátrio poder perante o Codigo Sovietico. Revista de Crítica Judiciária, Rio de Janeiro, v. 6, n. 6, dez 1927, p. 451.

22Veja: "O estudo que nos preocupa a atenção avulta de importância no Brasil. País novo, ainda não perfeitamente organizado e de vasta extensão territorial, onde, de dez anos a esta parte, se tem repetido o fenômeno com significativa frequência, o qual, ainda, se acha debaixo de sua influencia. A mencionada afirmação, só com respeito a países americanos, hoje, não tem os mesmos visos de verdade”. ALVIM, Osvaldo Ferraz. Direito de Revolução. Revista de Crítica Judiciária, Rio de Janeiro, v. 21, n. 2 e 3, fev./mar. 1925, p. 91.

Revista Brasileira de História do Direito | e-ISSN: 2526-009X| Encontro Virtual | v. 7 | n. 1 |

p. 40-63 | Jan/Jul. 2021. 
Acentua ainda mais essa questão, nos tempos convulsionados que perpassa a Revista de Crítica Judiciária, ao tratar-se do caso do integralismo e sua propaganda, que apesar de contrária a democracia, o julgador sentencia a favor da sua manutenção diante de denúncia do Procurador de República ${ }^{23}$. Justifica-se pela Lei de Segurança Nacional, a qual o movimento integralista sendo naquele instante partido político, uma sociedade legal. Ademais, por mais contrário ao estado democrático de direito que tal propaganda fosse não continha, segundo sentença, propaganda de guerra e de processos violentos, condizentes, portanto com a lei. Contudo, a lei deveria ser redigida de modo que não só se proibissem a propaganda de guerra ou a de processos violentos para subverter a ordem política e social, mas também a propaganda de regimes e ideias subversivas da ordem social e política da constituição brasileira, como critica a Revista (CORTES, 1936). Ao publicizar embates entre as mais variadas esferas que exerçam funções políticas, o periódico transgride com o auxílio da sua ferramenta crítica as percepções costumeiras publicadas pelo periodismo jurídico em seu tempo, preocupado muitas vezes em editar o expediente forense.

\section{REFERÊNCIAS}

ALVIM, Osvaldo Ferraz. Direito de Revolução. Revista de Crítica Judiciária, Rio de Janeiro, v. 21, n. 2 e 3, fev./mar. 1925, p. 91.

ASSIS, Jacy de. Qual a Constituição em vigor? Revista de Crítica Judiciária, Rio de Janeiro, v. 18, n. 4, out.1933, p. 257.

BARBOSA, Ruy. In: RODRIGUES, José Martins. A Unidade da Justiça e a organização constitucional. Revista de Crítica Judiciária, Rio de Janeiro, v. 14, n.1, jul. 1931, p. 4.

23Veja: "Por mais veemente e tendenciosa que seja essa propaganda, em prol de partido que tem como fim precípuo a implantação do absolutismo do Estado, como implantação de ditaduras, à feição das que ora enchem a Europa, de terrorismos internos e de furores internacionais, à custa das mais elementares liberdades e garantias dos cidadãos, não é tal propaganda vedada pelas leis nem podem ser acoimada, por si só, de subversiva". CORTES, Eloy Teixeira. Denuncia contra propagandista do integralismo. A democracia e os extremistas. Absolvição. Revista de Crítica Judiciária, Rio de Janeiro, v. 24, n.1, jul.1936, p.62. 
BEVILAQUA, Clovis. A futura Constituição. Revista de Crítica Judiciária, Rio de Janeiro, v. 14, n. 2, ago. 1931, p. 69.

CARNEIRO, Levi. A Comissão Legislativa. Revista de Crítica Judiciária, Rio de Janeiro, v. 13, n. 4, abr. 1931, p. 246.

CARVAlHO, Abílio de. Supremo Tribunal Federal. Revista de Crítica Judiciária, Rio de Janeiro, v. 9, n. 1, jan.1929, p. 6- 12.

CORTES, Eloy Teixeira. Denuncia contra propagandista do integralismo. A democracia e os extremistas. Absolvição. Revista de Crítica Judiciária, Rio de Janeiro, v. 24, n.1, jul.1936, p.62.

CUNHA, J. M. Leitão de. É oportuna a Constituinte? Revista de Crítica Judiciária, Rio de Janeiro, v. 14, n.1, jul. 1931, p. 2.

FERREIRA, Vieira. A Capital da República. Revista de Crítica Judiciária, Rio de Janeiro, v. 3, n. 6 , jun. 1926, p. 505 .

Autonomia Municipal. Revista de Crítica Judiciária, Rio de Janeiro, v.

8, n. 3, set. 1928, p. 155 .

Habeas-corpus contra remoção de juiz. Revista de Crítica Judiciária, Rio de Janeiro, v. 2, n. 4, out. 1925, p. 312.

É oportuna a constituinte? Revista de Crítica Judiciária, Rio de Janeiro, v. 13, n. 4, abr. 1931, p. 238.

FONSECA, Arnoldo Medeiros de. Supremo Tribunal Federal. Revista de Crítica Judiciária, Rio de Janeiro, v. 18, n. 4, out. 1933, p. 268.

JORDÃO, Edmundo de Miranda. É oportuna a Constituinte? Revista de Crítica Judiciária, Rio de Janeiro, v. 13, n. 5, mai. 1931, p. 316. 
KELLY, Prado. É oportuna a Constituinte? Revista de Crítica Judiciária, Rio de Janeiro, v. 13, n. 6, jun. 1931, p. 395.

LIMA, Augusto Pinto. Atos políticos. Abusos do Executivo. Supremacia do Poder Judiciário no regime. Revista de Crítica Judiciária, Rio de Janeiro, v. 8, n. 3, set. 1928, p. 162-163.

O Executivo e o sítio. Supremacia do Judiciário. Revista de Crítica

Judiciária, Rio de Janeiro, v. 4, n.2, ago. 1926, p. 135.

LIMA, Eusébio de Queiroz. É oportuna a constituinte? Revista de Crítica Judiciária, Rio de Janeiro, v. 13, n.4, abr. 1931, p. 242.

LIMA, Lourenço Moreiro. A nova Constituição. Revista de Crítica Judiciária, Rio de Janeiro, v. 18, n. 6, dez. 1933, p. 447.

MONTEIRO, Duglas Teixeira. Um confronto entre Juazeiro, Canudos e Contestado. In: O Brasil republicano, v. 2: sociedade e instituições (1889-1930) In: FAUSTO, Boris. (Org.) História Geral da Civilização Brasileira. Rio de Janeiro: Bertrand Brasil, 2004, p. 71.

MORAES, Evaristo de. Atentados da autoridade policial. Revista de Crítica Judiciária, Rio de Janeiro, v. 8, n. 1, jul. 1928, p. 44.

A reforma constitucional e a restrição do habeas-corpus. Revista de Crítica Judiciária, Rio de Janeiro, v. 2, n. 5, nov. 1925, p.481.

NOBREGA, J. Flóscolo da. À margem do anteprojeto de reforma da Justiça. Revista de Crítica Judiciária, Rio de Janeiro, v. 18, n. 4, out. 1933, p. 255.

PEREIRA, Eurico de Sá. Direitos políticos - Juízo privativo do direito de cidadania. Revista de Crítica Judiciária, Rio de Janeiro, v. 13, n.1, jan. 1931, p.11. 
QUEIROZ, Maurício Vinhas de. Messianismo e Conflito Social, A Guerra Sertaneja do Contestado - 1912-1916. Rio de Janeiro: Civilização Brasileira, 1966.

REICHARDT, H. Canabarro. É oportuna a Constituinte? Revista de Crítica Judiciária, Rio de Janeiro, v. 13, n. 5, mai.1931, p. 315.

REVISTA de Crítica Judiciária. O habeas-corpus e o estado de sítio. Revista de Crítica Judiciária, v. 2, n. 2, ago. 1925, p. 159.

Revista de Crítica Judiciária, Rio de Janeiro, v. 19, n. 6, jun. 1934, p. 443.

REZENDE, Astolpho. É oportuna a constituinte? Revista de Crítica Judiciária, Rio de Janeiro, v. 13, n. 4, abr.1931, p. 239.

REZENDE, Octavio Murgel de. É oportuna a Constituinte? Revista de Crítica Judiciária, Rio de Janeiro, v. 13, n. 6, jun. 1931, p. 396.

RODRIGUES, José Martins. A Unidade da Justiça e a organização constitucional. Revista de Crítica Judiciária, Rio de Janeiro, v. 14, n.1, jul. 1931, p. 6.

ROSA, Stéphani Fontes Esquecidas: uma reflexão histórica sobre o periodismo jurídico brasileiro pela (re)descoberta da Revista de Crítica Judiciária (1924-1940). Anais I Encontro Virtual do Conpedi, 2020.

SIMAS, Hugo. O pátrio poder perante o Codigo Sovietico. Revista de Crítica Judiciária, Rio de Janeiro, v. 6, n. 6, dez 1927, p. 451.

VAMPRÉ, Spencer. Intervenção federal para cumprimento de sentença judicial. Quando se justifica. Revista de Crítica Judiciária, Rio de Janeiro, v. 21, n. 4, abr.1935, p. 206.

VASCONCELLOS, José Mattos de. O Impechment dos Ministros do Supremo Tribunal Federal. Revista de Crítica Judiciária, Rio de Janeiro, v.1, n.5, mar. 1925, p.428 
VASCONCELLOS, Nilo C. L. de. A ordem jurídica e o sentimento de brasilidade. Revista de Crítica Judiciária, Rio de Janeiro, v. 15, n. 5, mai.1932, p. 317.

de. Presidente da República. Revista de Crítica Judiciária, Rio de Janeiro, v. 24, n. 4, out.1936, p. 325-326. 